\title{
Influence of Varying Rates of Fertilizers on the Performance of Cacao (Theobroma cacao) Seedlings in the Nursery
}

\author{
Idowu B. Famuwagun $^{1^{*}}$ and Oladitan Titilayo $\mathrm{O}^{2}$ \\ ${ }^{1}$ Department of Crop, Soil and Pest Management, Federal University of Technology, Akure Nigeria \\ ${ }^{2}$ Rufus Giwa Polytechnic, Owo, Nigeria \\ ”ibfamuwagun@futa.edu.ng
}

Keywords: cacao, fertilizer products, fertilizer rate, growth, seedling quality.

\begin{abstract}
Effects of application of poultry manure, organo-mineral fertilizer, NPK soil or foliar applied at varying rates on cacao seedlings were studied in the nursery between January-May 2011 and December to April, 2012. Poultry manure at 40,50 and 60g/plant significantly influenced cacao seedlings height and number of leaves over other treatments. The effect of organo-mineral fertilizer application at 50 and $60 \mathrm{~g}$ per plant on the number of leaves was also significantly better than NPK soil or foliar applied, starting from 12 weeks after treatment application. The stem girth development under poultry manure at 50 and $60 \mathrm{~g}$ per plant application had the best performance followed by poultry manure at $40 \mathrm{~g}$ per plant. There were no significant differences in almost all the treatments at 5 weeks after sowing on seedlings stem girth. NPK has the longest tap root length while poultry manure had the largest average number of lateral roots followed by organo-mineral. The results thereby indicated that the use of poultry manure at 40 to $50 \mathrm{~g}$ per plant and organomineral fertilizer as sources of nutrients had significant effects on cacao seedling quality.
\end{abstract}

\section{Introduction}

Cacao (Theobroma cacao L.) is a tropical woody species which belong to the family Malvaceae [1]. The geographical origin of cacao is South America [2], where several wild populations can be found in the Amazon and Guyanian regions. It is considered one of the most important perennial crops with an estimated world output of 3.5 million tonnes in 2006 [3]. It is one of the tropical crops that required raising the seedlings in the nursery before transplanting to the permanent field [4]. In cacao seedling production, adequate nutrients supply is essential for optimum growth and development both at nursery and in the field after transplanting [5]. In recent years, several reports revealed decrease in establishment percentage of transplanted cacao seedlings due to poor seedling development from the nursery, poor farm management practices and soil and air moisture stresses [6]. These problems were also compounded by deficiencies of both macro and micro nutrients [7], which had resulted in drastic reduction in the yield of such plantations. Also there is need to supply adequate nutrients to cacao seedling at the nursery stage to aid root and shoot development [6]. Many field reports gives an average of less than $40 \%$ survival in most cases, which has resulted in significant losses for farmers [8]. Effective management of cacao seedlings in the nursery using appropriate agronomic practices like fertilization, dry season irrigation, and appropriate self-multiplying bio fertilizer like AMF to enhance root development will enhance seedling growth and gives optimum field establishment [9]. However, very few studies have tried to determine the appropriate fertilizer products and the application rates in the nursery in the Nigerian context. The objective of the study was therefore to: assess proper fertilization of cacao in nursery to raise healthy and vigorous seedlings so as to provide good transplantable seedlings that can well adapt to field conditions so as to facilitate early establishment of the just transplanted seedlings and growth. Various fertilizer materials were used at variable rates to determine the suitable product and rates. 


\section{Materials and Methods}

An experiment was conducted between January and May 2011 and repeated in 2012 in the Teaching and Research Farm of the Federal University of Technology, Akure, Nigeria within the rainforest zone to investigate the effects of fertilizers application on cacao seedling growth and development in the nursery. The treatments involved were $\mathrm{N}: \mathrm{P}: \mathrm{K}(15: 15: 15)$ soil applied at $15 \mathrm{~g}$, $20 \mathrm{~g}, 25 \mathrm{~g}$ per seedling), N:P:K (15:15:15) folia applied (40, 50 and $60 \mathrm{ml} /$ litre of water), Sunshine organo-mineral fertilizer $(40,50$ and $60 \mathrm{~g} / \mathrm{plant})$ and poultry manure $(40,50,60 \mathrm{~g} / \mathrm{plant})$. The forms of the NPK in the fertilizers were ammonium nitrate for N, single superphosphate (SSP) $20 \% \mathrm{P}_{2} \mathrm{O}_{5}$ for $\mathrm{P}$ and potassium chloride $(\mathrm{KCl})$ for $\mathrm{K}$. The Sunshine organo-mineral used was an organic fertilizer that was fortified with essential nutrient to meet various crop demands with $3.5 \% \mathrm{~N}, 2.5 \%$ $\mathrm{P}_{2} \mathrm{O}_{5}$ and $1.5 \% \mathrm{~K}_{2} \mathrm{O}$, while the poultry manure contained $3.2 \% \mathrm{~N}$. It is worth mentioning that the application rates used in this study were not adjusted to supply the equivalent amount of nutrients in each treatment. Black polythene pots of $4.5 \times 10 \mathrm{~cm}$ were filled with top soil from a well fallowed forest. The planting materials (cacao bean from freshly harvested pod) from the Cacao Research Institute of Nigeria (CRIN), Owena sub-station, Akure, Ondo State and were sown at one seed per pot. The experiments were set up in a randomized compete block design (RCBD) with each treatment having five replicates. Watering was carried out at two days interval throughout the period of the experiment. The fertilizer treatments were applied at two weeks after sowing at the specified rates for the soil application and folia fertilizers in a two split application at 2 and 12 weeks after sowing to enhance timely availability and reduce loss due to leaching and oxidation of essential nutrients.

Data collection from the raised seedlings was scheduled at every 2 weeks interval after the application of the fertilizers; however, only data at 4 weeks interval are presented. Data collected include plant height, number of leaves and stem girth as well as root parameters The root parameters were taken at 16 weeks after sowing and include tap root, length and number of lateral roots,. The data were subjected to analysis of variance (ANOVA) using SPSS and the means were separated using Duncan's New Multiple Range Test (DNMRT).

\section{Results}

\section{Seedling height}

Application of poultry manure positively influenced cacao seedlings development in term of plant height which is significantly higher compared with other fertilizer treatments across the various rates of application in 2011 experiment. In 2012 experiment, a similar trend was observed, except for the data sets collected at 8 weeks after sowing (WAS). NPK folia applied at 40ml/litre, NPK soil applied at 20g/plant and organo-mineral fertilizer applied at $40 \mathrm{~g} / \mathrm{plant}$ were not significantly different from those recorded with poultry manure applied at $40 \mathrm{~g}$ and $50 \mathrm{~g}$ per plant at 8 WAS as shown in Table $1(\mathrm{P} \leq 0.05)$. Organo-mineral fertilizer application significantly enhanced cacao seedlings plant height compared to NPK folia applied, NPK soil applied and the control but were significantly lower compared with those recorded in poultry manure treated seedlings (Table 1).

Table 1. Effects of varying rates of fertilizer application on plant height $(\mathrm{cm})$ of cacao seedlings in the nursery

\begin{tabular}{|c|c|c|c|c|c|c|}
\hline \multirow[t]{2}{*}{ Treatments } & \multicolumn{3}{|c|}{ Weeks after sowing in 2011} & \multicolumn{3}{|c|}{$\begin{array}{l}\text { Weeks after sowing in } \\
2012\end{array}$} \\
\hline & 8 & 12 & 16 & 8 & 12 & 16 \\
\hline NPK folia applied @40ml & $22.0 \mathrm{cde}$ & $27.0 \mathrm{cdef}$ & $31.0 \mathrm{bcd}$ & $24.2 \mathrm{a}$ & $26.0 \mathrm{bc}$ & $32.5 \mathrm{cdef}$ \\
\hline NPK folia applied @,50ml & $19.7 \mathrm{def}$ & $24.4 \mathrm{efg}$ & 28.4de & $21.3 \mathrm{bc}$ & $25.1 \mathrm{~cd}$ & 31.6def \\
\hline NPK folia applied @60ml & $16.90 \mathrm{f}$ & $31.4 \mathrm{abc}$ & $33.4 \mathrm{bcd}$ & $22.0 \mathrm{~b}$ & $25.7 \mathrm{~cd}$ & $32.4 \mathrm{cdef}$ \\
\hline NPK soil applied @15g/plant & 20.4de & $23.8 \mathrm{efg}$ & 29.8bcde & $21.3 \mathrm{bc}$ & $26.0 \mathrm{bc}$ & $34.0 \mathrm{cde}$ \\
\hline NPK soil applied @20g/plant & 20.9 cde & $22.6 f g$ & $23.8 \mathrm{e}$ & $25.0 \mathrm{a}$ & $28.4 b$ & $36.2 \mathrm{bc}$ \\
\hline
\end{tabular}




\begin{tabular}{|l|l|l|l|l|l|l|}
\hline NPK soil applied @25g/plant & $22.7 \mathrm{bcd}$ & $26.4 \mathrm{def}$ & $28.8 \mathrm{cde}$ & $21.2 \mathrm{bc}$ & $25.7 \mathrm{bcd}$ & $33.4 \mathrm{cde}$ \\
\hline $\begin{array}{l}\text { Organo-mineral } \\
\text { fertilizer@40g/plant }\end{array}$ & $20.2 \mathrm{de}$ & $30.4 \mathrm{abcd}$ & $35.6 \mathrm{~b}$ & $24.0 \mathrm{ab}$ & $28.5 \mathrm{~b}$ & $37.5 \mathrm{bc}$ \\
\hline $\begin{array}{l}\text { Organo-mineral } \\
\text { fertilizer@50g/plant }\end{array}$ & $22.0 \mathrm{bcde}$ & $27.8 \mathrm{bcde}$ & $35.8 \mathrm{~b}$ & $20.0 \mathrm{bc}$ & $25.3 \mathrm{~cd}$ & $37.8 \mathrm{bc}$ \\
\hline $\begin{array}{l}\text { Organo-mineral } \\
\text { fertilizer@60g/plant }\end{array}$ & $20.1 \mathrm{de}$ & $24.8 \mathrm{efg}$ & $29.6 \mathrm{bcde}$ & $21.4 \mathrm{bc}$ & $27.5 \mathrm{~b}$ & $37.0 \mathrm{bc}$ \\
\hline Poultry Manure@40g/plant & $26.6 \mathrm{ab}$ & $33.8 . \mathrm{a}$ & $42.6 \mathrm{a}$ & $24.8 \mathrm{a}$ & $30.3 \mathrm{a}$ & $43.6 \mathrm{ab}$ \\
\hline Poultry Manure@50g/plant & $24.6 \mathrm{ab}$ & $32.0 \mathrm{ab}$ & $48.0 \mathrm{a}$ & $25.1 \mathrm{a}$ & $32.6 \mathrm{a}$ & $44.2 \mathrm{ab}$ \\
\hline Poultry Manure@60g/plant & $24.6 \mathrm{ab}$ & $21.6 \mathrm{~g}$ & $31.6 \mathrm{bcd}$ & $22.3 \mathrm{~b}$ & $33.3 \mathrm{a}$ & $46.7 \mathrm{a}$ \\
\hline Control & $23.9 \mathrm{abc}$ & $27.8 \mathrm{bcde}$ & $31.8 \mathrm{bcd}$ & $21.9 \mathrm{bc}$ & $26.0 \mathrm{bc}$ & $32.5 \mathrm{cdef}$ \\
\hline
\end{tabular}

Means in same column followed by same letter(s) are not significantly different $P \leq 0.05$ using Tukey Test.

\section{Number of leaves of the seedlings}

Poultry manure treated seedlings producing a significantly higher number of leaves in the two trials compared with other fertilizer treatments (Table 2). However, no marked difference among the three rates of fertilizer application in term of number of leaves produced for NPK soil and foliar applied, poultry manure, and the organo-mineral fertilizers $(\mathrm{P} \leq 0.05)$.

\section{Seedling stem girth}

In 2011 experiment, with $(\mathrm{P} \leq 0.05)$ NPK foliar applied showed a significantly thicker seedling stem girth compared with the other treatments, while in 2012 experiment, the stem girth development was significantly higher in seedlings treated with poultry manure $(40,50$ and $60 \mathrm{~g} / \mathrm{plant}$ ), NPK foliar applied (40g/litre), and organo-mineral fertilizer (40 and 50g/plant) compared with the other treatments (Table 3 ).

Table 2. Effects of varying rates of fertilizer application on number of leaves

\begin{tabular}{|l|l|l|l|l|l|l|}
\hline \multirow{2}{*}{ Treatments } & \multicolumn{2}{|l|}{ Weeks after sowing in 2011 } & \multicolumn{2}{l|}{ Weeks after sowing in 2012 } \\
\cline { 2 - 7 } & 8 & 12 & 16 & 8 & 10 & 16 \\
\hline NPK folia applied @40ml & $5.8 \mathrm{bcde}$ & $7.0 \mathrm{bcd}$ & $8.4 \mathrm{def}$ & $6.2 \mathrm{bc}$ & $7.5 \mathrm{bcd}$ & $8.8 \mathrm{def}$ \\
\hline NPK folia applied @,50ml & $6.8 \mathrm{abcd}$ & $8.0 \mathrm{abcd}$ & $9.0 \mathrm{cdef}$ & $6.1 \mathrm{bcd}$ & $7.3 \mathrm{bcd}$ & $9.4 \mathrm{cdef}$ \\
\hline NPK folia applied @660ml & $5.2 \mathrm{de}$ & $8.0 \mathrm{abcd}$ & $9.0 \mathrm{cdef}$ & $6.0 \mathrm{bcd}$ & $7.6 \mathrm{bcd}$ & $8.9 \mathrm{def}$ \\
\hline NPK soil applied @15g/plant & $6.2 \mathrm{bcde}$ & $8.4 \mathrm{abcd}$ & $11.1 \mathrm{abcd}$ & $6.2 \mathrm{bc}$ & $7.8 \mathrm{abcd}$ & $10.6 \mathrm{cde}$ \\
\hline NPK soil applied @20g/plant & $7.6 \mathrm{abc}$ & $9.0 \mathrm{abc}$ & $8.2 \mathrm{def}$ & $6.3 \mathrm{bc}$ & $8.2 \mathrm{abc}$ & $11.6 \mathrm{bc}$ \\
\hline NPK soil applied @25g/plant & $7.8 \mathrm{a}$ & $9.0 \mathrm{abc}$ & $9.0 \mathrm{cdef}$ & $7.5 \mathrm{a}$ & $8.6 \mathrm{a}$ & $11.3 \mathrm{bc}$ \\
\hline $\begin{array}{l}\text { Organo-mineral } \\
\text { fertilizer@40g/plant }\end{array}$ & $6.6 \mathrm{abcd}$ & $7.8 \mathrm{abcd}$ & $10.2 \mathrm{cdef}$ & $6.0 \mathrm{bcd}$ & $8.1 \mathrm{abc}$ & $11.2 \mathrm{bcd}$ \\
\hline $\begin{array}{l}\text { Organo-mineral } \\
\text { fertilizer@50g/plant }\end{array}$ & $6.6 \mathrm{abcd}$ & $8.4 \mathrm{abcd}$ & $10.8 \mathrm{bcde}$ & $6.7 \mathrm{ab}$ & $8.6 \mathrm{a}$ & $11.0 \mathrm{bcd}$ \\
\hline $\begin{array}{l}\text { Organo-mineral } \\
\text { fertilizer@60g/plant }\end{array}$ & $5.8 \mathrm{bcde}$ & $6.8 \mathrm{~cd}$ & $6.8 \mathrm{f}$ & $6.1 \mathrm{bcd}$ & $7.7 \mathrm{bcd}$ & $10.8 \mathrm{cde}$ \\
\hline Poultry Manure@40g/plant & $7.2 \mathrm{abc}$ & $9.6 \mathrm{ab}$ & $14.0 \mathrm{ab}$ & $6.5 \mathrm{abc}$ & $8.4 \mathrm{ab}$ & $12.6 \mathrm{ab}$ \\
\hline Poultry Manure@50g/plant & $8.0 \mathrm{a}$ & $9.8 \mathrm{a}$ & $14.4 \mathrm{a}$ & $6.8 \mathrm{abc}$ & $8.3 \mathrm{ab}$ & $13.5 \mathrm{a}$ \\
\hline Poultry Manure@60g/plant & $6.2 \mathrm{abcd}$ & $6.0 \mathrm{~d}$ & $12.4 \mathrm{abc}$ & $6.5 \mathrm{abc}$ & $7.8 \mathrm{abcd}$ & $12.4 \mathrm{ab}$ \\
\hline Control & $6.8 \mathrm{abcd}$ & $7.4 \mathrm{abcd}$ & $8.2 \mathrm{def}$ & $7.0 \mathrm{ab}$ & $8.1 \mathrm{abc}$ & $8.9 \mathrm{def}$ \\
\hline
\end{tabular}

Means in same column followed by same letter(s) are not significantly different $P \leq 0.05$ using Tukey Test. 
Table 3. Effects of varying rates of fertilizer application on stem girth $(\mathrm{cm})$

\begin{tabular}{|c|c|c|c|c|c|c|}
\hline \multirow[t]{2}{*}{ Treatments } & \multicolumn{3}{|c|}{$\begin{array}{l}\text { Weeks after sowing in } \\
2011\end{array}$} & \multicolumn{3}{|c|}{$\begin{array}{l}\text { Weeks after sowing in } \\
2012\end{array}$} \\
\hline & 8 & 12 & 16 & 8 & 12 & 16 \\
\hline NPK folia applied @40ml & $0.62 \mathrm{a}$ & $0.82 \mathrm{a}$ & $0.90 \mathrm{~b}$ & $0.72 \mathrm{a}$ & $0.87 \mathrm{ab}$ & $0.99 \mathrm{a}$ \\
\hline NPK folia applied @,50ml & $0.46 \mathrm{de}$ & $0.65 \mathrm{cde}$ & $0.76 \mathrm{~b}$ & $0.58 \mathrm{~b}$ & $0.75 \mathrm{bcd}$ & $0.82 \mathrm{abc}$ \\
\hline NPK folia applied @60ml & 0.42 def & $0.64 \mathrm{cde}$ & $1.18 \mathrm{a}$ & $0.58 \mathrm{a}$ & $0.78 \mathrm{abcd}$ & $0.86 \mathrm{abc}$ \\
\hline NPK soil applied @15g/plant & $0.48 \mathrm{def}$ & $0.58 \mathrm{de}$ & $0.89 \mathrm{~b}$ & $0.62 \mathrm{a}$ & $0.74 \mathrm{bcd}$ & $0.81 \mathrm{abc}$ \\
\hline NPK soil applied @20g/plant & 0.42 def & $0.56 \mathrm{~b}$ & $0.62 \mathrm{~b}$ & $0.59 \mathrm{a}$ & $0.58 \mathrm{e}$ & $0.62 \mathrm{~d}$ \\
\hline NPK soil applied @25g/plant & $0.52 \mathrm{bcd}$ & $0.66 \mathrm{cde}$ & $0.76 \mathrm{~b}$ & $0.64 a$ & $0.76 \mathrm{bcd}$ & $0.79 \mathrm{~cd}$ \\
\hline Organo-mineral fertilizer@40g/plant & 0.42 def & $0.71 b c$ & $0.83 \mathrm{~b}$ & $0.56 \mathrm{a}$ & $0.78 \mathrm{abcd}$ & $0.85 \mathrm{abc}$ \\
\hline Organo-mineral fertilizer@50g/plant & $0.52 \mathrm{bcd}$ & $0.71 \mathrm{bc}$ & $0.83 b$ & $0.66 \mathrm{a}$ & $0.78 \mathrm{abcd}$ & $0.90 \mathrm{ab}$ \\
\hline Organo-mineral fertilizer@60g/plant & $0.40 \mathrm{ef}$ & $0.58 \mathrm{de}$ & $0.70 \mathrm{~b}$ & $0.58 \mathrm{a}$ & $0.66 \mathrm{de}$ & $0.78 \mathrm{~cd}$ \\
\hline Poultry Manure@40g/plant & $0.58 \mathrm{ab}$ & $0.70 \mathrm{bc}$ & $0.88 \mathrm{~b}$ & $0.64 a$ & $0.84 \mathrm{abc}$ & $0.93 \mathrm{ab}$ \\
\hline Poultry Manure@50g/plant & $0.48 \mathrm{cde}$ & $0.70 \mathrm{bc}$ & $1.13 \mathrm{~b}$ & $0.63 \mathrm{a}$ & $0.85 \mathrm{abc}$ & $0.99 a$ \\
\hline Poultry Manure@60g/plant & $0.36 \mathrm{f}$ & $0.68 \mathrm{bcd}$ & $1.12 \mathrm{~b}$ & $0.52 \mathrm{a}$ & $0.90 \mathrm{a}$ & $1.0 \mathrm{a}$ \\
\hline Control & $0.56 \mathrm{abc}$ & $0.77 \mathrm{ab}$ & $0.96 \mathrm{~b}$ & $0.67 \mathrm{a}$ & $0.90 \mathrm{a}$ & $0.75 \mathrm{~cd}$ \\
\hline
\end{tabular}

Means in same column followed by same letter(s) are not significantly different $P \leq 0.05$ using Tukey Test.

\section{Seedling root system}

In both 2011 and 2012 experiments, tap root length was enhanced significantly through the application of organo-mineral fertilizer at $60 \mathrm{~g} /$ plant, NPK soil applied at $15 \mathrm{~g} / \mathrm{plant}$ and the control compared with other treatments. No significant difference in the tap root length among poultry manure and organo-mineral treated seedlings (Table 4). Lateral root number were significantly higher with treatments involving organo-mineral fertilizer at $60 \mathrm{~g} / \mathrm{plant}$ and poultry manure at $60 \mathrm{~g} / \mathrm{plant}$ compared with other treatments $(\mathrm{P} \leq 0.05)$.

Table 4: Effects of fertilizers application on root parameters of cacao seedlings

\begin{tabular}{|l|l|l|l|l|l|l|}
\hline \multirow{2}{*}{ Treatments } & \multicolumn{3}{|c|}{2011 season } & \multicolumn{3}{c|}{2012 season } \\
\cline { 2 - 7 } & $\begin{array}{l}\text { Tap root } \\
\text { length } \\
\text { (cm) }\end{array}$ & $\begin{array}{l}\text { Number of } \\
\text { lateral root }\end{array}$ & $\begin{array}{l}\text { Average } \\
\text { length of } \\
\text { lateral root } \\
\text { (cm) }\end{array}$ & $\begin{array}{l}\text { Tap root } \\
\text { length } \\
\text { (cm) }\end{array}$ & $\begin{array}{l}\text { Number of } \\
\text { lateral root }\end{array}$ & $\begin{array}{l}\text { Average } \\
\text { length of } \\
\text { lateral root } \\
\text { (cm) }\end{array}$ \\
\hline NPK folia applied @40ml & $18.3 \mathrm{abc}$ & $54.0 \mathrm{~d}$ & $11.3 \mathrm{~d}$ & $16.2 \mathrm{abc}$ & $59.0 \mathrm{~d}$ & $13.4 \mathrm{~d}$ \\
\hline NPK folia applied @,50ml & $13.3 \mathrm{f}$ & $65.7 \mathrm{c}$ & $13.3 \mathrm{abcd}$ & $12.5 \mathrm{f}$ & $61.6 \mathrm{c}$ & $13.7 \mathrm{abcd}$ \\
\hline NPK folia applied @60ml & $20.3 \mathrm{a}$ & $63.7 \mathrm{c}$ & $12.0 \mathrm{~cd}$ & $22.14 \mathrm{a}$ & $73.7 \mathrm{c}$ & $11.6 \mathrm{~cd}$ \\
\hline NPK soil applied @,15g/plant & $18.3 \mathrm{abc}$ & $44.0 \mathrm{e}$ & $8.3 \mathrm{e}$ & $18.0 \mathrm{abc}$ & $55.0 \mathrm{e}$ & $9.2 \mathrm{e}$ \\
\hline NPK soil applied @20g/plant & $17.0 \mathrm{bcd}$ & $52.3 \mathrm{~d}$ & $12.7 \mathrm{bcd}$ & $17.25 \mathrm{bcd}$ & $57.3 \mathrm{~d}$ & $10.3 \mathrm{bcd}$ \\
\hline NPK soil applied @25g/plant & $16.7 \mathrm{bc}$ & $52.0 \mathrm{~d}$ & $12.3 \mathrm{bcd}$ & $18.6 \mathrm{bcde}$ & $65.0 \mathrm{~d}$ & $11.1 \mathrm{bcd}$ \\
\hline $\begin{array}{l}\text { Organo-mineral } \\
\text { fertilizer@40g/plant }\end{array}$ & $16.0 \mathrm{~cd}$ & $61.0 \mathrm{c}$ & $12.2 \mathrm{~cd}$ & $17.2 \mathrm{de}$ & $72.3 \mathrm{c}$ & $13.5 \mathrm{~cd}$ \\
\hline $\begin{array}{l}\text { Organo-mineral } \\
\text { fertilizer@50g/plant }\end{array}$ & $14.7 \mathrm{ef}$ & $52.3 \mathrm{~d}$ & $12.2 \mathrm{~cd}$ & $16.7 \mathrm{ef}$ & $76.5 \mathrm{~d}$ & $13.8 \mathrm{~cd}$ \\
\hline $\begin{array}{l}\text { Organo-mineral } \\
\text { fertilizer@60g/plant }\end{array}$ & $16.3 \mathrm{bc}$ & $85.0 \mathrm{a}$ & $15.7 \mathrm{a}$ & $17.25 \mathrm{a}$ & $87.0 \mathrm{a}$ & $15.6 \mathrm{a}$ \\
\hline Poultry Manure@40g/plant & $15.3 \mathrm{cde}$ & $63.3 \mathrm{c}$ & $12.0 \mathrm{~cd}$ & $15.5 \mathrm{def}$ & $83.3 \mathrm{c}$ & $12.5 \mathrm{~cd}$ \\
\hline Poultry Manure@50g/plant & $16.3 \mathrm{bc}$ & $74.3 \mathrm{~b}$ & $11.7 \mathrm{~cd}$ & $16.7 \mathrm{bcde}$ & $78.5 \mathrm{~b}$ & $11.4 \mathrm{~cd}$ \\
\hline Poultry Manure@60g/plant & $16.2 \mathrm{bc}$ & $82.7 \mathrm{a}$ & $15.0 \mathrm{ab}$ & $17.7 \mathrm{cde}$ & $86.7 \mathrm{a}$ & $15.3 \mathrm{ab}$ \\
\hline Control & $18.5 \mathrm{abc}$ & $65.0 \mathrm{c}$ & $14.2 \mathrm{abc}$ & $18.0 \mathrm{ab}$ & $45.0 \mathrm{c}$ & $12.0 \mathrm{abc}$ \\
\hline
\end{tabular}

Means in same column followed by same letter(s) are not significantly different $P \leq 0.05$ using Tukey Test. 


\section{Discussion}

The significantly higher plant height obtained in poultry manure application at 40,50 and $60 \mathrm{~g}$ per plant was attributed to the fact that poultry manure contains reasonable amount of nitrogen and other essential nutrients that are essential for plant growth and development [10]. More so, it contain reasonable amount of calcium and magnesium which increases the elemental content of the soil [11]. [12, 6] reported seedling vigour as a key factor in cacao seedling quality which is determine by plant height, stem girth, number of leaves, and root system. The non-significant seedlings plant height under NPK soil applied may be due to the effects of watering method which imposed a leaching effect on the elemental nutrients supplied by the mineral fertilizer which was in line with the findings of [13] that top watering in potted plants enhances increased leaching losses. Foliar applied NPK has the lowest performance in term of plant height; this may be as a result of volatile nature of the nitrogen which reduced its availability to the seedlings or minimum intake of the foliar applied nutrients. Poultry manure may also present a competitive advantage of slow released nutrients, which would minimize losses during watering compared to NPK soil and foliar applied. This was in conformity with the earlier findings that organic manures are usually slow in mineralization [14]. NPK soil applied and NPK foliar applied have reduced number of leaves which may be accounted for by the ammonium ion present as nitrogen source that may reduce soil $\mathrm{pH}$ thereby causing soil acidity ([15], [16]. This assumption seems valid as the control showed better performance than the NPK treatments, although further studies may be required to validate the observation. Changes in soil $\mathrm{pH}$ such as acidification might cause nutrient unavailability to the seedling and consequently affect the seedling quality.

The poultry manure performance on seedling stem girths in the study was in line with the report of [17] that poultry manure contains high percentage of nitrogen, phosphorus and potassium at steady state. The gradual release of nutrient in poultry manure and organo-minerals fertilizer pave way for uniform growth and development in term of increased number of lateral roots both at the lower and the upper part of the tap root and higher average length of the lateral roots.

The fertilizer application rates were not adjusted to deliver the same rates of nutrients such as $\mathrm{N}, \mathrm{P}$, or K. Hence, there is a need to cross-validate the findings of this study in a similar assessment where the fertilizer rates are adjusted for at least one of the major nutrients. This will be useful to fine-tune the fertilizer recommendations for cacao seedlings. It is particularly important as the best performance was obtained with poultry manure whose quality may be affect by seasonal and feeding variability in addition to the manure management. An economic analysis of the various fertilizer products when applied at the rate adjusted based on the nutrient content of at least one of the major nutrients would also be necessary to determine the most cost-effective treatment.

\section{Conclusion}

Application of different types of fertilizer has enhanced cacao seedlings development in the nursery with appreciable effects. The poultry manure and the organo-mineral fertilizer did perform better than the inorganic NPK soil or foliar applied as at the study rates for production of high quality seedlings based on height, leaf numbers, stem girth, and root system. This finding should be validated through application of equivalent amount of at least one of the major nutrients $(\mathrm{N}, \mathrm{P}$, or $\mathrm{K})$ in all the fertilizer treatments for robust recommendation.

\section{Acknowledgements}

My sincere appreciation goes to Professor Samuel O. Agele, Dr M. A. Awodun and Mrs D.Y. Famuwagun for their support towards the success of this research study. 


\section{References}

[1] W.S. Alverson et al., Phylogeny of the core Malvales: evidence from ndhF sequence data, Am. Journals of Botany. 86 (1999) 1474-1486.

[2] J.C. Motamayor et al., Cacao domestication 1: the origin of cacao cultivated by Mayas, Heredity. 89(5) (2002) 380-386.

[3] International Cocoa Organization Annual Report (ICCO, 2007) pp. 23-25.

[4] S.A. Adenikinju, E.B. Esan, A.A. Adeyemin, Nursery Techniques, Propagation and Management of Cacao, Kola, Coffee, Cashew and Tea, Progress in Tree Crop research (Second Edition) A Commemorative Book to mark the $25^{\text {th }}$ Anniversary of CRIN, 1989.

[5] N.E. Egbe, Fertilizer on growth and yield of cocoa in Cocoa Research, Institute of Nigeria annual report. (1968) 41-43.

[6] I.B. Famuwagun, S.O. Agele, Effects of sowing methods and plant population densities on root development of cacao seedlings in the nursery, International Journal of Agricultural $\backslash$ Research. 5(7) (2011) 445-452

[7] S.A. Ayanlaja, Soil Nutrient Management Research in the Humid Forest Zone of Nigeria for Cacao Production between 1940 and 2000, Tropical agriculture (Trinidad). 64 (2002) 237-240.

[8] O.S. Ibiremo et al., Effect of root mat management and phosphate fertilizer application on the field establishment of cocoa in Ondo state, Nigeria, International journal of plant, animal and environmental sciences. 2(2) (2012) 18-25.

[9] J.N. Smith, Cocoa production systems, option and constraints, Cocoa Growers' Bulletin. 47 (1994) 20-26.

[10] J.F. Parri, S.B. Hornick, D.D. Kanfwan, Extension bulletin (ASPC/FFTC), 1994.

[11] P.M. Ahp, A text book on West Africa soil, Oxford University press, 1979.

[12] K. Wilson, Coffee, Cocoa and Tea: Crop Production Science Horticulture, number 8, CABI Publishing, Wallingford, 1999.

[13] S.O. Agele, S. Adeosun, D. Oluwadare, A lysimeter study of nutrient release characteristics, leaching losses and effects on growth response of Amaranthus resulting from application of inorganic and organic nitrogen sources, Journal of Food, Agriculture and the Environment. 2(2) (2004) 301-306.

[14] G.A. Ayeni, Effect of sole and combined cocoa pod ash, poultry manure and NPK 20:10:10 fertilizer on soil organic carbon, available phosphorus and form of nitrogen on alfisol in southwest Nigeria, International research journal of agricultural and soil science. 1 (2011) 77-82.

[15] S.O. Ojeniyi, Effect of bush clearing and tillage methods on soil physical and chemical properties of humid alfisol, Soil tillage research. 15 (1991) 269-277.

[16] I.B. Famuwagun, F.O. Adekayode, Effect of wood ash, poultry manure and NPK fertilizer on growth, yield and seed quality of soya bean, Applied tropical agriculture. 15 (2010) 143-146.

[17] B.S. Ewulo, Effect of poultry dung and cattle manure on chemical properties of clay and sandy clay loamy soil, Journal of animal and vetenary advancement. 4 (2005) 839-841. 